\title{
CONCEPTUAL DESIGN OF QUALITY MANAGEMENT DIGITALIZATION FOR FMCG INDUSTRY
}

\section{Septian Sugestyo Putro, Sugeng Santoso}

Universitas Mercu Buana (UMB) Jakarta, Indonesia

Email: septiankuliahlagi@gmail.com, sugeng.santoso@mercubuana.ac.id

\begin{abstract}
Industry 4.0 era encourage FMCG manufacture industries in Indonesia to continuously innovating through digital technology adoption in their process, including quality management. Quality management digitalization in manufacture industry in Indonesia is now at the level of leaving paperwork documentation and analog communication in quality control; and have started to adopt computerized database and analysis. The absent of national software provider and academic study focusing on quality management digitalization concept has become an obstacle for Indonesia to evolve in Industry 4.0 era. This paper intended to provide conceptual design of integrated quality management digitalization to support FMCG industries in effective decision making and compliance to quality control plan; and to stimulate national software provide to develop digitalized quality management program.
\end{abstract}

Keywords: Digitalization; quality management; FMCG; industry 4.0; concept

Received: 2021-12-20; Accepted: 2022-01-05; Published: 2022-01-15

\section{Introduction}

Manufacturing industry in Indonesia has become one business sector that that directly impacted by Covid-19 pandemic in its capability of slowing down global economic activities. The industrial practitioners must deliver the best they can do for their organization to survive in the hard moment, with exploring any strategic management possibility in order to prevent them getting involved onto worsened crisis. One of the possible strategies is to make sure the product delivered to market have fulfill the standard quality requirement. 


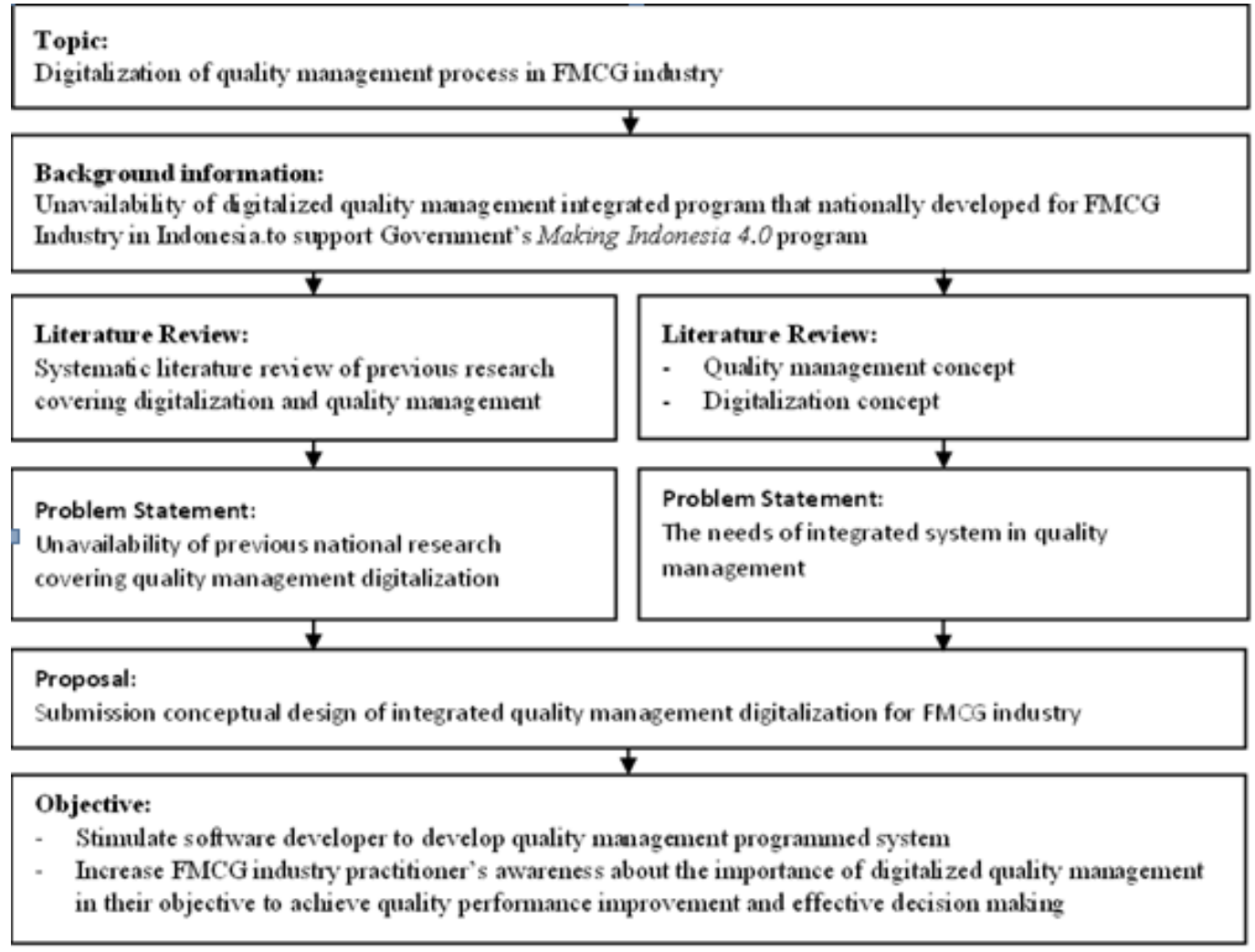

Figure 1

\section{Framework of Thinking in Concepting Digitalized Quality Management}

Industry 4.0 era enable manufacture industry to have enormous opportunities to survive, or even grow, during a crisis like Covid-19 pandemic through the implementation of ERP (Enterprise Resource Planning) technology, e-procurement, production process automation, and not limited to process conversion from human activity-based to robotic in production process. All the opportunities mentioned share common goal; to keep customer satisfaction, to continuously have competitive advantages in the market, and to ensure all products produced and delivered to market are products that meets the standard quality requirement. In fact, these goals are not a simple and easy to be achieved. Human error, information flow limitation, and complex document management become significant obstacle for fast moving consumer goods (FMCG) manufacturer in their attempt to achieve the goals. For FMCG industries, high demand accuracy is almost impossible and production volume fluctuation urge the quality management must be always in its optimal performance (Bottani, Montanari, \& Volpi, 2010).

In FMCG's journey to digitalization era, quality management become one of the subjects that is often looked at one eye and or neglected, it is not considered as top priority in their transformation plan. Indonesia as a growing country, mainly utilize the local expert in strengthening the supply-side capabilities with development in human resource (Wie, 2000). Manufacturing industries in Indonesia still put their primary focus on the implementation of lean and process improvement through digitalization, while 
digitalization in quality management remain as a side-kick topic that is still too taboo to be deeply explored. The limited number of national program and system developer that having the capability of integrating quality management process, and the enormous amount of investment required to build one, become significant barriers for manufacturing industry practitioner in Indonesia to implement digitalization transformation in this subject. Unavailability of studies and research related to design and concept development of integrated digital management quality program that generally easy to adopt, become another challenge for digital program developer. In order to close the institutional void, this article created to formulate concept design of quality management digitalization for FMCG industries with their goals to leverage quality performance and decision-making effectiveness. The concept also intended to stimulate national software developer to design affordable quality management digital program. The article's framework of thinking can be observed at Figure 1.

1. Industry 4.0

One situation that clearly identified as Industry 4.0 characteristic is the declining of human activity involvement, as an impact of adopting systematic interction between machine instrument. In the Industry 4.0 era, highly skilled human resource also holds important roles to keep the industry have competitive advantage in the market (Tritularsih \& Sutopo, 2017). Communication between interfaced instrument become highly evolving along with rapid grows of manufacture process digitalization. Industry 4.0 stimulates introduction to digital technology and invites beneficial factor to a better operation efficiency (Luz Martín-Peña, Díaz-Garrido, \& Sánchez-López, 2018). At the same context, (Hadi \& Murti, 2019) in their article conclude that in the era of Industry 4.0, integration of digital information become a key factor that very important in managing manufacturing and logistic process to achieve more effective and efficient business process.

Indonesia has started the movement to anticipate and prepare the nation to face Industry 4.0 era with a national program launching known as Making Indonesia 4.0 through Government's Ministry of Industry. Making Indonesia 4.0 focused on 5 industrial sectors as pilot baselines in strengthen the national industrial structure. One of the sectors is food and drink product that classifies as FMCG industry (Kemenperin.go.id, 2018). In his article, (Satya, 2018) concludes 4 strategic movement socialized by Indonesian Ministry of Industry:

a. Leveraging competition in adopting internet of things

b. Adopting process digitalization to increase productivity of small and middle industry level

c. development of digital technology for industry in national scale

d. stimulate the growth of technology-based start-up companies.

Baselined by Making Indonesia 4.0 roadmap formulated by Ministry of Industry, digitalization in FMCG industry become an important key factor in the nation's attempt to increase the growth of industrial technology in Indonesia. It will need national scale technology developers with high competency and capabilities to 
understand and analyze the needs of local industries and generate innovation in providing digitalized process capable to support the production and quality performance improvement.

2. Quality management

Lean, Six Sigma, and Lean Six Sigma are not new terms in Indonesia manufacture industry in their goals to adopt Zero Defect Manufacturing practice (ZDM). Quality management can be defined as a part of supply chain management in its focus to increase customer satisfaction through conformance to standar and procedure; and the effectiveness of decision making in respecting customer rights at the same time with minimizing the risk of loss for the organization (Lim, 2019). The importance of maintaining quality management performance determines the credibility of a manufacturing company in maintaining consumer trust, by implementing standardization, national and international certifications, compliance audits, and management of responses to feedback and complaints from customers.

(Juran \& Godfrey, 1999) in their book Juran's Quality Handbook, explain that in implementing quality management, 3 important factor called Juran's Trilogy should be ensured to exist, they are (1) Quality Planning; (2) Quality Control; and (3) Quality Improvement. Quality planning determines the quality standard of a product that is intended to meet consumer needs. Quality control ensures a product to stay within the standard quality range. In this process, 7 Quality Control Tools are still quite relevant in their application in the FMCG industry, even though Industry 4.0 has entered a new type of 7 Quality Control Tools (Shigeru, 1988). Meanwhile, quality improvement is an effort to continuously improve quality performance by reducing product damage during the production process, reducing consumer complaints and increasing process efficiency.

In line with Juran's quality trilogy, in ISO 9126 quality modeling also uses the same approach in defining quality as a collection of product characteristics both externally in the form of functional requirements, and internally in the form of structure, size, dimensions, and material characteristic of a product. These characteristics included into quality planning, designed in such a way to be able to meet customer needs. Document standardization, compliance certification, and accreditation treated as the formal guidelines and references in designing quality control process. Quality control is the second part in Juran's Quality trilogy focused in monitoring process by measuring product characteristics, both its raw material and processes that must be executed periodically to make sure standard compliance that has been agreed in quality planning. The quality control process must always ensure compliance to agreed standard procedures. In the 3rd Juran trilogy, the audit process, ZDM and the elimination of defects are the steps that determine the direction of quality improvement.

3. Quality Management Digitalization

Digitalization can be defined as a process conversion of analog information flow to digital information flow (Gobble, 2018). Digitalization in industrial sector 
according to (Bloomberg, 2018) concluded as part of interaction and business process transformation in an organization from initial condition in the form of analog communication (verbal, paper document, phone call) to become digital communication method (electronic transmission, e-mail, system connection, internet). Based on these definition form both researcher, quality management digitalization can be defined as transformation of quality monitoring, product standard and procedure documentation, and process compliance audit from analog communication and paper-based to become paperless and integrated digitalized process. Digitalization can also come in the form of transforming people-to-people (P2P) communication onto people-to-machine (P2M) communication or even machine-to-machine (M2M) communication. However, P2M communication believed to be needed in the near future as human-thinking ability still crucial to decision-making process, that need to consider factors that cannot be calculated nor anticipated by artificial intelligence, such as political situation, market trends, and the organization's financial aspect. In other hand, M2M with arterial intelligence in recent technology update, do not have capability of creating such human-like decision making.

\section{Method}

Research in this article is using descriptive qualitative method, supported by Systematic Literature Review (LSE) that reviews previous national scale research within 3 years period to defend the relevancies in comparison with current technology update. The research literature review was proceeded with using digital search engine and database, in this article Garuda (garuda.ristekbrin.go.id) as national academic indexing portal and Mendeley desktop application are used with filtering article publication within 3 years period covering from 2017 to 2020. The publication filtered in the form of books and journal-published article. The literature search activity was using 3 keywords combination with each combination consist of two words, they are (1) "Digitalisasi Mutu"; (2) "Digitalisasi Industri"; and (3) "Digitalisasi Quality". These keyword filters intended to limit only national literation that focusing in digitalization and quality topics that appeared in the search result. The SLE Framework illustrated in Figure 2. 


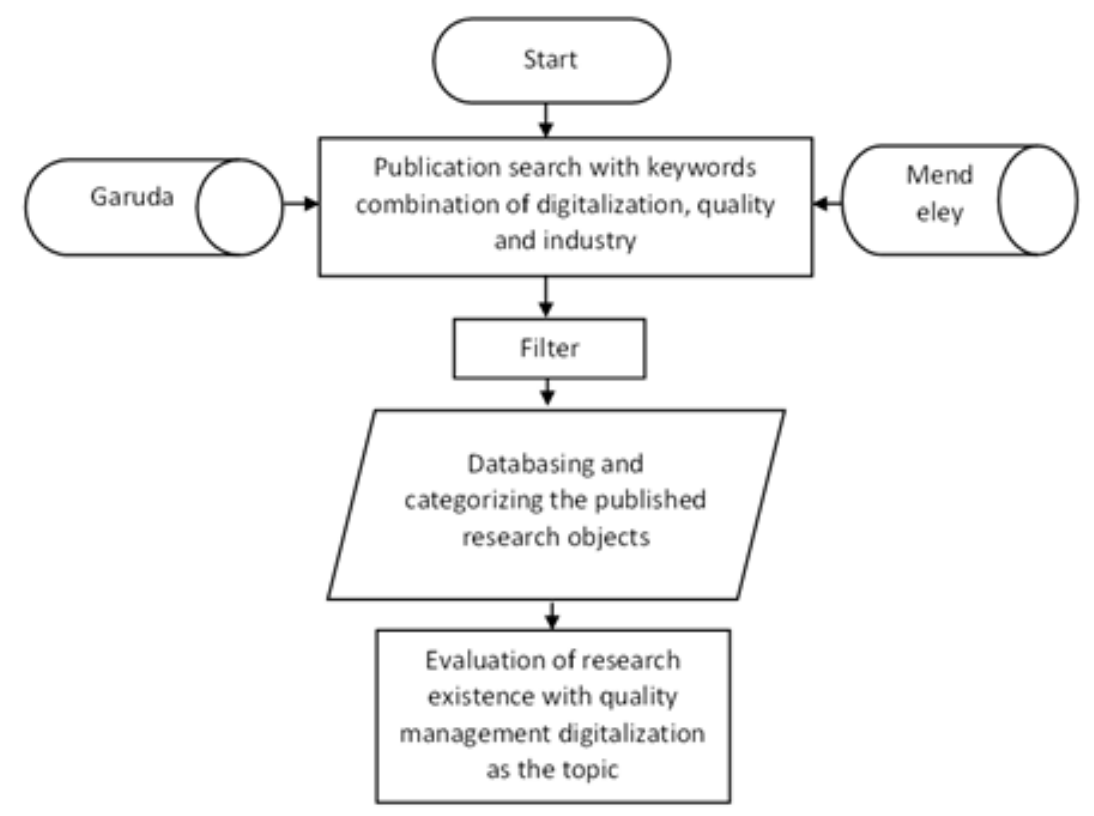

Figure 2

SLE Research Method Framework

Mendeley and Gaurda Indexing Portal are utilized due to their capability in indexing complete national publication, offers simplification in searching process, and provide filters based on publication years. From the searching results, publication shown on the indexing engines then databased to be examined and made sure if there any previous publication that already focused on quality management digitalization and followed by analyzing the frequency of how often quality management digitalization become the research object.

On the descriptive qualitative method, the research formulized important elements of quality management that have high possibility to be utilized in digitalization component based on research of digitalization and quality concept. Integrated digitalization transformation design developed with using baseline from Juran's Quality Trilogy and ISO 9261, through describing the purpose and objective of each elements and what kind of digital feature that should be available to achieve the objective. Both research method results then combined as a baseline for design proposal of integrated digital system framework of quality management in fast moving consumer goods industry.

\section{Result and Discustion}

SLE method with utilizing Garuda indexing portal and Mendeley desktop application generate result of 87 publication related with keywords combination "Digitalisasi industri", "Digitalisasi mutu", and "Digitalisasi quality". All articles published between 2017 to 2020 . We then run through each of the paper, review their title and abstract, then each of the paper categorized onto 6 commonly known categories 
related to digitalization, they are social finance, information technology, production, logistic, and quality. Number of papers in each category are shown in Graph1.

SLE with the combination of keywords that have been mentioned shows the fact that the discussion of digitization with the specified keywords takes more objects in the fields of social and information technology. This also proves that quality management studies do not get sufficient.

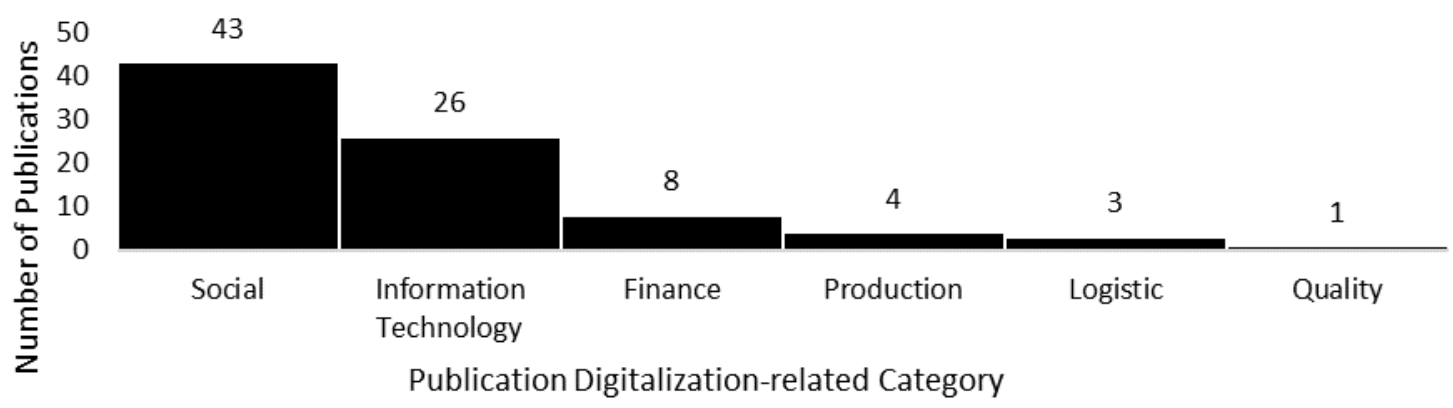

\section{Graph 1. Digitalization Publication Searching Result using SLE}

Attention from the topic of national publications in the field of digitization. The only publication related to digital quality management is research related to web applications to accommodate the digitalization of ISO quality management, developed by (Susilo \& Rohman, 2017), but this article does not cover the systematics of digitizing quality control and management in the FMCG industry.

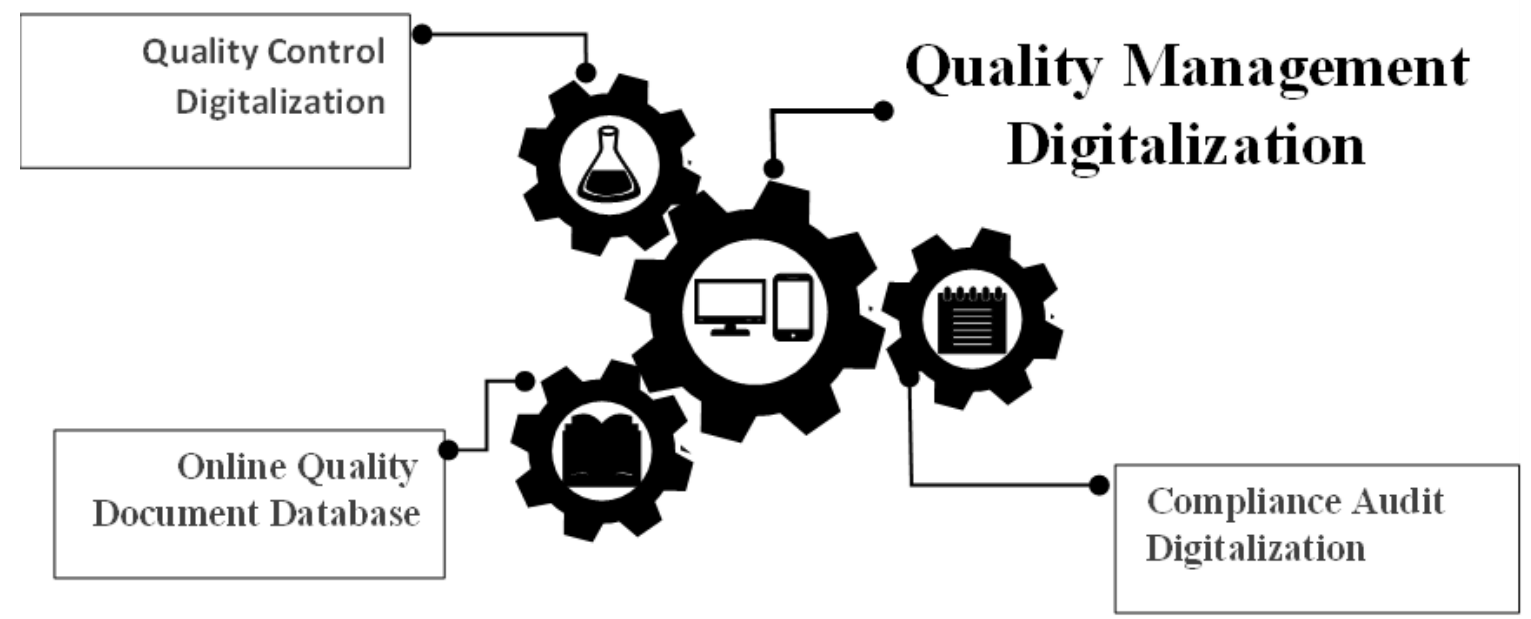

Figure 3. Main Digitalization Concept Design

Through a qualitative descriptive method, this research departs from the Juran Trilogy and ISO 9126 to formulate 3 essential aspects to become the driver of a digitalized quality management. The main design concepts in digitizing quality management are illustrated in Figure 3, where the aspects that support digital transformation are (1) Quality control digitalization; (2) Enabling online database 
consisting standard quality, procedure and certification document; and (3) Compliance audit process digitalization in accordance with applicable standards and procedures.

1. Online Quality Database

Online quality database is part of the first chapter of Juran's Quality Trilogy which formulize quality planning through standardized document of product characteristic, certification, and/or accreditation of a specific product. Digitalization in this part intended to have objective as follow:

a. Increase the knowledge and awareness of each member of the company on quality guidelines

b. Reducing non-conformance processes

c. Increase the capability of the quality controllers

The achievement of these objectives is accomplished by building a quality database that provides systematic document management, visual-friendly and systematically integrated. All documents that were previously stored in the form of books, posters or loose-leaf paper, are transformed into digitally available documents that are easily accessible either via a computer device or a handheld mobile device. This Online Quality Database Design should have digital features as shown in Figure 4.

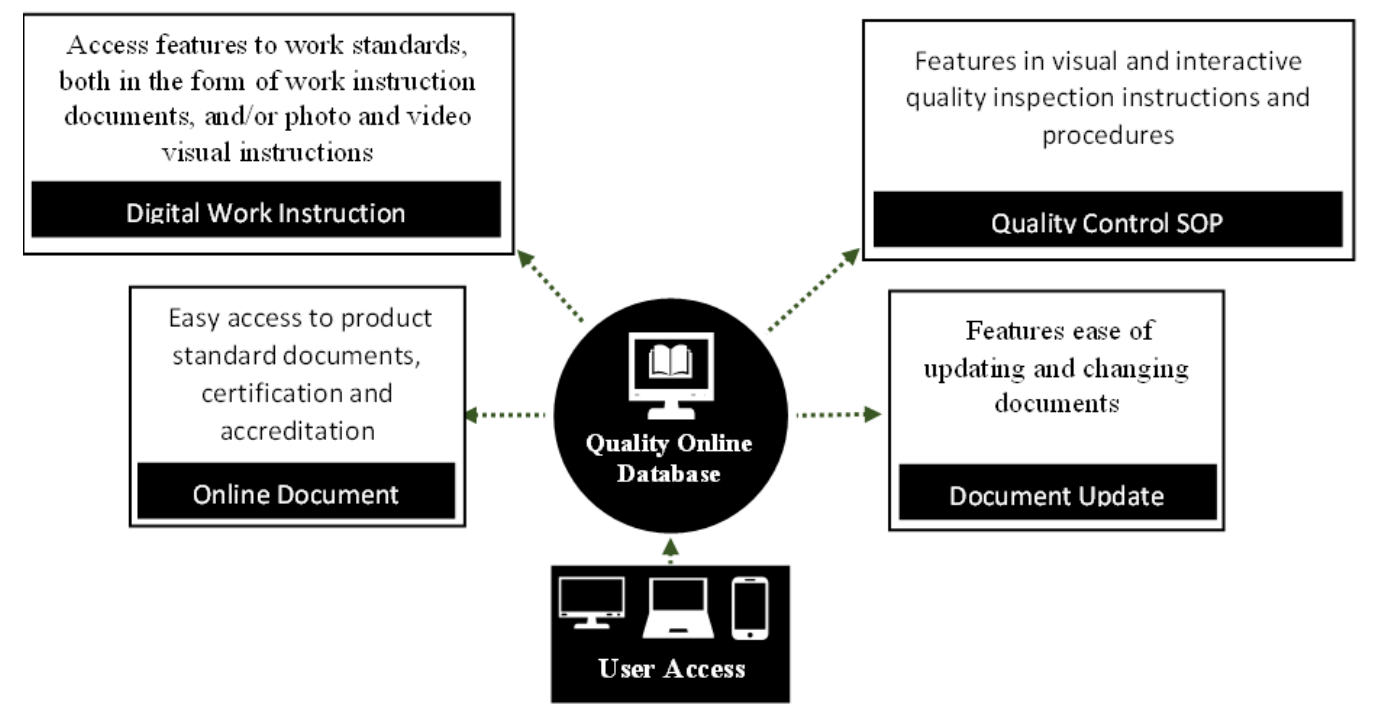

Figure 4. Online Quality Database Feature Design

With the online database feature for quality planning, it can transform traditional conditions where documents are stored in physical form and require a large storage area, into modern conditions that only require a few computer devices with the benefit of easy to access. The benefits of digital transformation in this process is illustrated in Figure 5. 


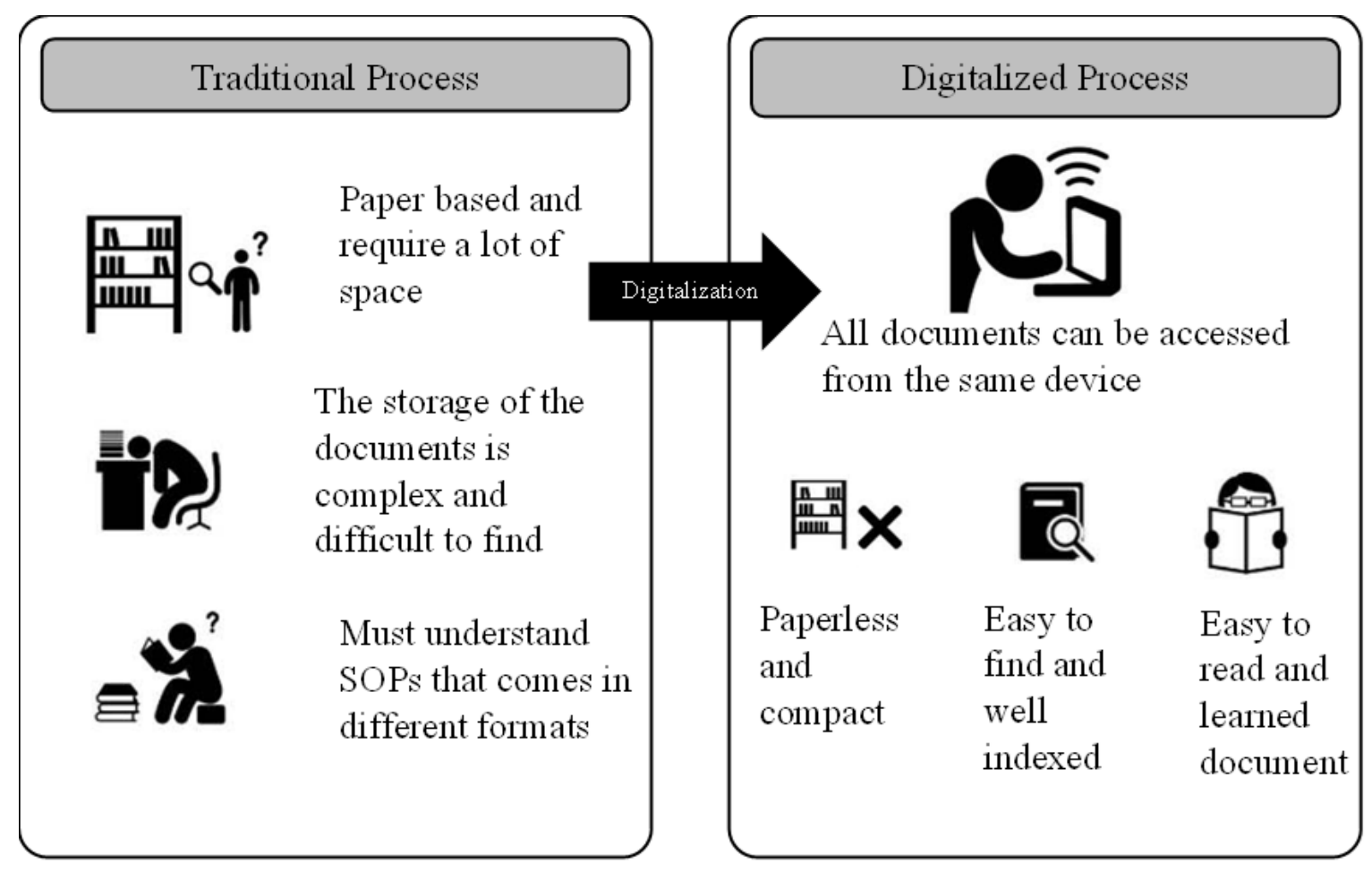

Figure 5. Benefits of Digital Quality Database

2. Quality Control Digitalization

Quality control is the second part of Juran's quality trilogy, defined as the process of quality control through inspection of all parameters required to be met in carrying out production activities in the FMCG industry. All of parameter involving work-in-process material (WIP) specification standards, packaging requirement standards, room condition requirements, up to finished good standards, can be digitally monitored. In this process, digitization designed to have objective as follow:

a. Ensuring the lowest possible level of product defect

b. Ensuring all production outputs released are in accordance with product standards

This goal is achieved by providing reliable data, visualizing data that is easy to understand, and data with good traceability. The need for controlled quality parameters will be different for each FMCG Industry, depending on standards, business processes, and types of commodities processed. Digitalization of quality control plays an important role in the decision-making process; the design of this process is depicted in Figure 6. Product and process standards that have been designed at the quality planning stage, become an important database that is used as a reference by the system in the process of analyzing quality inspection results.

The Master Data stores the parameters of each product characteristic that becomes the standard for good or bad quality of the product, for example the range of product dimensions, the range of contents of beverage or food products, or the temperature range in the heating process of food dough. Master Data can also be a 
reference system in providing warnings or information of when and where the quality checking process should be carried out, what type of product, how many samples to check, which batch number, to the personal protective equipment that needs to be worn..

Each data resulting from the actual measurement of the quality character of a product, raw material and production process, is entered into the computer system. The system then matches the results of the inspection data with the predetermined standard quality characteristics. The analysis process runs automatically and the results will be displayed visually in the form of a dashboard on a screen. This dashboard displays the results of real-time computer analysis, thus helping every member of the company in monitoring the quality performance of a production process. Whenever there is an abnormal condition where the results of the examination are not within agreed standards, the system through the dashboard will display a warning notification / alarm alert, to encourage immediate action. In this process, P2M interaction occurs, where the results of computer analysis become important data references for decision makers whether production needs to be stopped or just needs a quick fix so that production can continue.

The results of data analysis in the form of this warning will then become important data for a preventive action plan so that the same incident can be reduced or even eliminated in the future. This evaluation process is also carried out based on the analysis data generated by the system that working based on problem categorization, the frequency of occurrence of problems, to the level of risk that has been predetermined in the master data. The analysis process of quality inspection results can be programmed in such a way as to be able to be displayed in a visual form of 7 Quality Control Tools such as stratification, histogram, scatter diagram, control chart, Paretto diagram, and check sheet. Fish-bone diagrams require complex logic to be an automated media system, but it is easier to be presented digitally by providing a template that can be filled in to make it easier for users to identify problems.

At a more complex system level, this quality measurement design can be integrated with the production process directly for production lines that utilize machines equipped with digital control panels. Hence the parameters of the production machine can be recorded immediately and can be analyzed automatically. In the next system integration, digital quality inspection results with indications of causing high product damage and increasing risk, can generate an automated order to stop the operation of the machine. This is useful in reducing the increase in product defects and reduce risk by requiring prompt treatment to address the source of the problem before resuming production. 


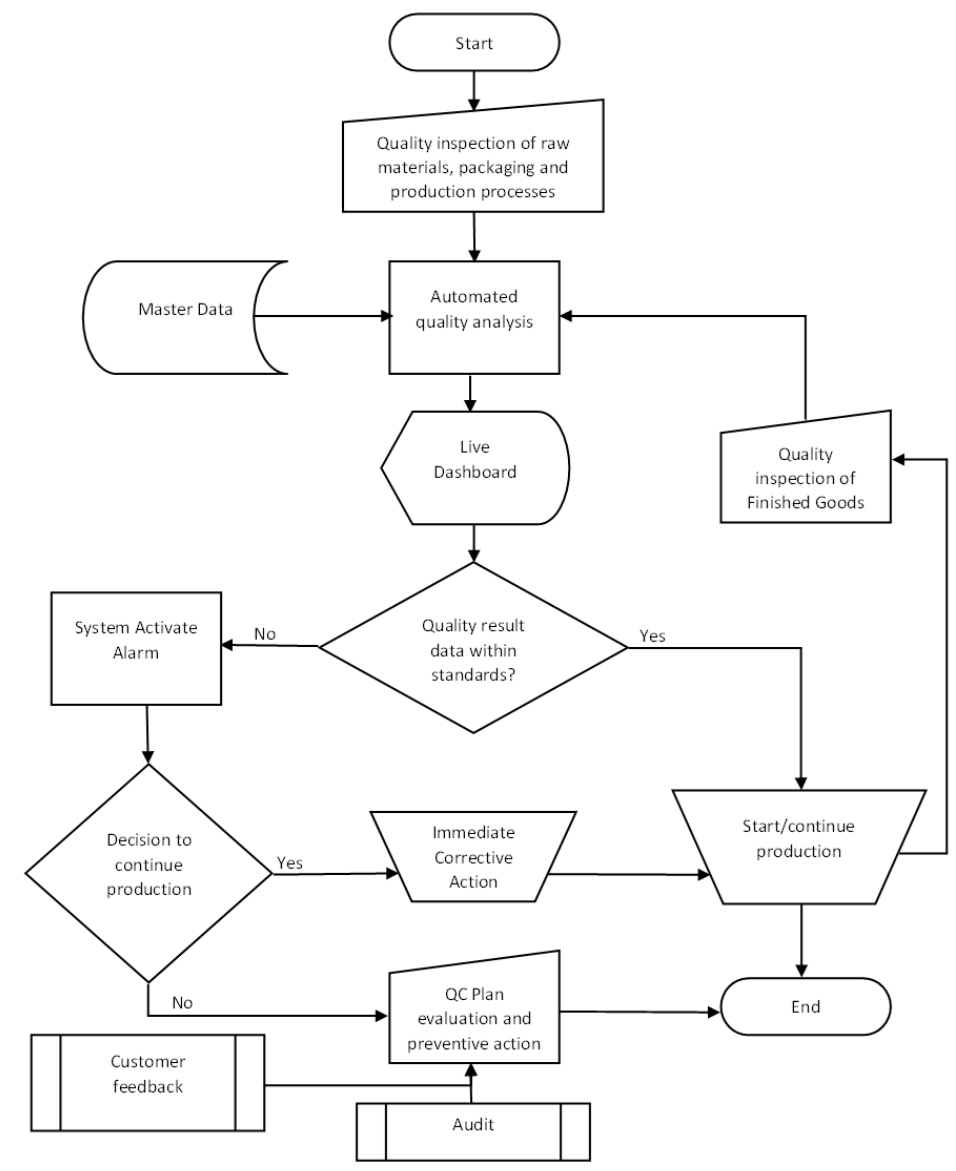

Figure 6. Digitalized Quality Control Flow Design

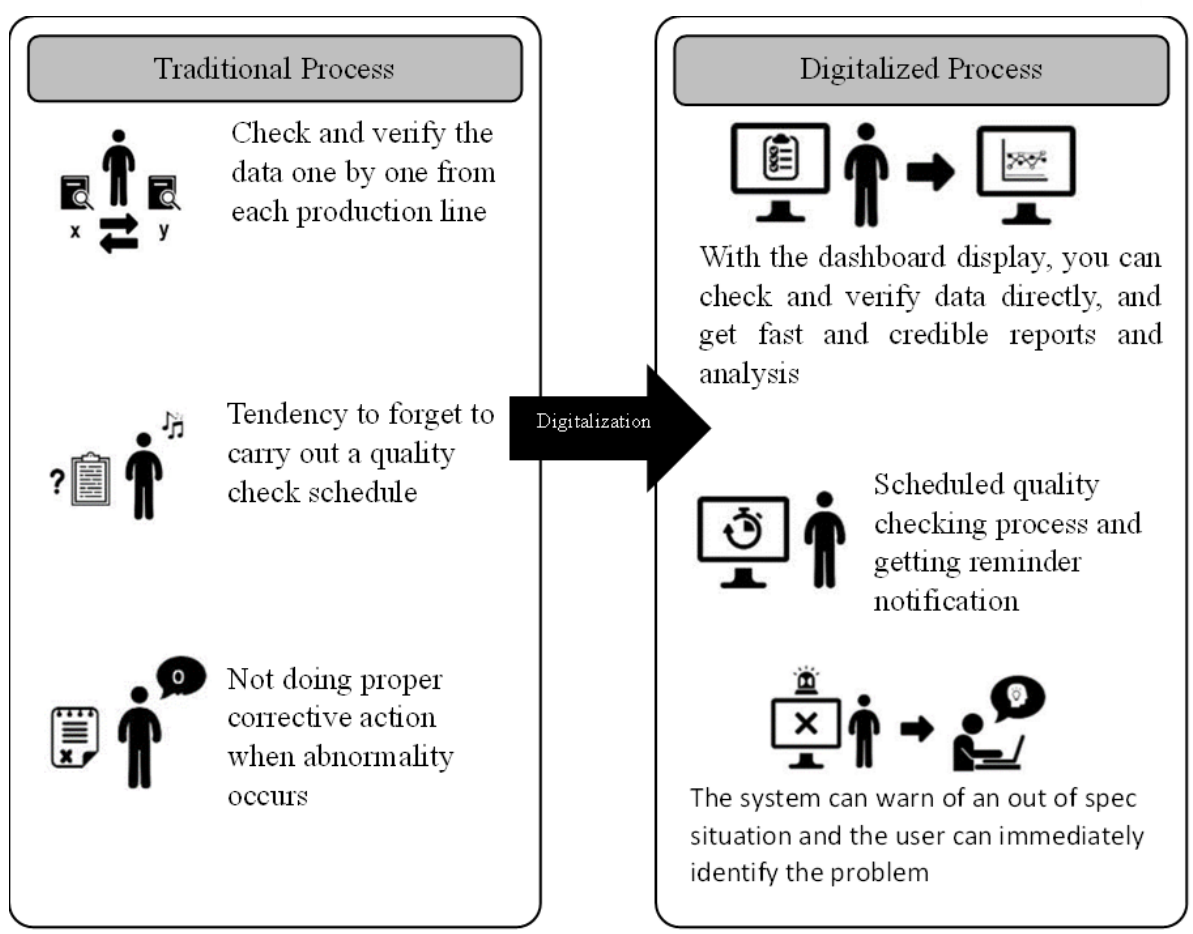

Figure 7. Benefits of Digitalized Quality Control 
The digitization of the quality checking process is the most complex design compared to the other 2 elements, considering that this process is a data collection process for quality analysis and is involved in handling various kinds of product characteristics and parameters of production process conditions. Every member of the organization must be committed to provide correct and accurate data entry process to maintain the reliability of the system applied, so that it can bring the benefits of digital transformation which is illustrated in Figure 7.

3. Compliance audit digitalization

Audits are needed to maintain the consistency of a process to adhere to applicable standards and procedures. The audit process can be carried out internally by involving members of the organization or externally by involving a certification organization or consultant. Digitalization can be carried out in the process of internal audit activities where audits are held regularly and cross-functionally. Digitalization of the audit process aims to:

a. Improve the effectiveness and efficiency of the audit process

b. Increase compliance to standard requirements

c. Help the organization to prepare for external audits

To achieve these objectives of digitalization, a digital audit system needs to have features that allow auditors to have guidance on audit objects and their requirements, as well as features that allow direct input of audit finding data into the system. The data from the audit findings are then collected and processed as justification for corrective action design. The features in Figure 8 shows a digitalized audit system design that integrates all elements of this internal audit into a single system.

The digitalized audit process leads the auditors to abandon the use of paper in preparing audit checklists and making reports on the audit results. The ease of tracking CAP audit findings and saving time are other benefits that the digital audit process will able to provide. 


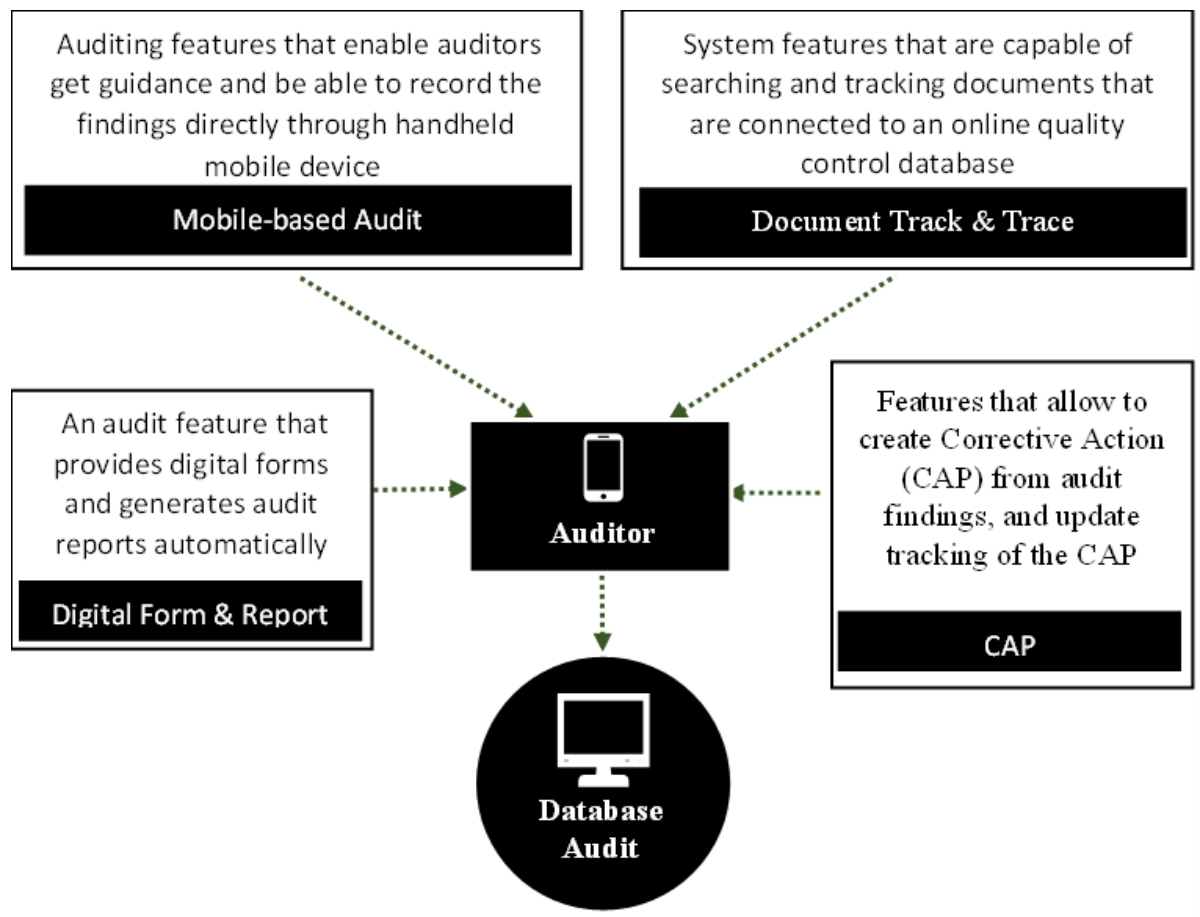

Figure 8. Benefits of Digitalized Compliance Audit

\section{Best practice}

Not many FMCG industry players or researchers in Indonesia have enough courage and dare to take the risk in taking a step forward in developing a quality management system through digital transformation in Indonesia. It will need companies like Coca-Cola Amatil Indonesia (CCAI) that is recognized as best companies in developing digitalized quality management system with its Quinsys program. The company utilized its internal IT and Supply Chain resource to build an integrated system than enable to create more opportunity to process effectiveness and efficiency. The recognition as Best Digital Transformer 2019 for CCAI is awarded by International Digital Corporation, also known as reputable digital application company IDC.com, (2019) (Dirgantara \& Devie, 2019).

5. Benefits to Industrial Organization

Other than many benefits gained from the system feature, digitalized quality management can invite benefits in industrial organization. Simplified process and minimized paperwork will generate opportunities in reducing unnecessary activity in quality management process, therefore the organization can review the efficiency of manpower needed in this part. There are opportunities to reduce the number of people that previously doing quality control and parameter checking, because with digitalized quality management, it may not need that much people to proceed the task. Process efficiency in through digitalization become the most effective ways gaining manpower efficiency in Industry 4.0 era (Parviainen, Tihinen, Kääriäinen, \& Teppola, 2017). 


\section{Conclusion}

Transformation through digitalization is not an instantaneous process and will continue to evolve following technological developments. The benefits gained from digitalized quality management are able to significantly shorten the process, at the same time increasing the effectiveness and efficiency of quality control in order to maintain product quality and customer trust and satisfaction. Companies with digitalized quality management will have better preparation to face competition in Industrial 4.0 era. The concept in this article is expected to be a stimulus for FMCG industry players and digital software program developers to apply and develop an integrated system in maintaining, monitoring and developing quality management technology, as part of Indonesian journey to Making Indonesia 4.0. 


\section{BIBLIOGRAFI}

Bloomberg, Jason. (2018). Digitization, digitalization, and digital transformation: confuse them at your peril. Forbes. Retrieved on August, 28, 2019. Google Scholar

Bottani, Eleonora, Montanari, Roberto, \& Volpi, Andrea. (2010). The impact of RFID and EPC network on the bullwhip effect in the Italian FMCG supply chain. International Journal of Production Economics, 124(2), 426-432. Google Scholar

Dirgantara, Deka Bayu, \& Devie, Erika. (2019). The Influence Of Price, Perceived Quality, And Brand Image On Customer Post Purchase Behaviour Of Frestea At Pt Coca Cola Amatil Indonesia Semarang. JOBS (Jurnal Of Business Studies), 4(2), 105-118. Google Scholar

Gobble, MaryAnne M. (2018). Digitalization, digitization, and innovation. ResearchTechnology Management, 61(4), 56-59. Google Scholar

Hadi, Suharman, \& Murti, Hari Wisnu. (2019). Kajian industri 4.0 untuk penerapannya di Indonesia. Jurnal Manajemen Industri Dan Logistik, 3(1), 1-13. Google Scholar

Juran, Joseph M., \& Godfrey, A. Blanton. (1999). The quality control process. McGraw-Hill. Google Scholar

Lim, Jong S. (2019). Quality Management in Engineering: A Scientific and Systematic Approach. CRC Press. Google Scholar

Luz Martín-Peña, María, Díaz-Garrido, Eloísa, \& Sánchez-López, José María. (2018). The digitalization and servitization of manufacturing: A review on digital business models. Strategic Change, 27(2), 91-99. Google Scholar

Parviainen, Päivi, Tihinen, Maarit, Kääriäinen, Jukka, \& Teppola, Susanna. (2017). Tackling the digitalization challenge: how to benefit from digitalization in practice. International Journal of Information Systems and Project Management, 5(1), 6377. Google Scholar

Satya, Venti Eka. (2018). Strategi Indonesia menghadapi industri 4.0. Info Singkat, 10(9), 19-24. Google Scholar

Shigeru, Mizuno. (1988). Management for quality improvement. The 7 New QC Tools, 1988. Google Scholar

Susilo, Purnomo Hadi, \& Rohman, M. Ghofar. (2017). Digitalisasi Sistem Manajemen MUTU ISO Berbasis Aplikasi Web. Jurnal Penelitian Teknik Informatika, 2(1), 45-50. Google Scholar

Tritularsih, Yustina, \& Sutopo, Wahyudi. (2017). Peran Keilmuan Teknik Industri Dalam Perkembangan Rantai Pasokan Menuju Era Industri 4.0. Seminar Dan Konferensi Nasional IDEC, 1(2017), 8-9. Google Scholar 
Septian Sugestyo Putro, Sugeng Santoso

Wie, Thee Kian. (2000). Raising Indonesia's Industrial Competitiveness. Economics and Finance in Indonesia, 48, 35-61. Google Scholar

\section{Copyright holder:}

Septian Sugestyo Putro, Sugeng Santoso (2022)

\section{First publication right:}

Syntax Literate: Jurnal Ilmiah Indonesia

\section{This article is licensed under:}

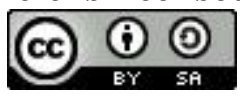

